\title{
Reorientasi Pendidikan Agama Di Sekolah
}

\author{
M. Zainuddin
}

Penulis adalah Dosen Fak. Tarbiyah Universitas Islam Negeri (UIN) Malang

\section{ABSTRACT}

It is not false to be said that the history of civilization is the history of human being, because in the reality, human being is the civilized creature that has ethics. Therefore, he needs education and teaching to make himself mature and developed, but he must get religious education to make himself mature. In other words, the importance of religion is not merely the letters compiled into law, but, the spirit of its religion, namely faith and affection is more important. Through that education, it is expected that the learners will have ideal personality, high solidarity, honesty, justice, harmony and get far from disintegration, violence, conflict and tension among the followers of religion.

Hingga saat ini bangsa Indonesia masih terus dihadapkan pada persoalan yang melilit bangsa: krisis ekonomi, krisis sosial, dan krisis moral. Budaya kekerasan, korupsi, kolusi, dan otoritarianisme telah mengakar sedemikian rupa. Berbagai persoalan, baik sosial, ekonomi, politik maupun budaya begitu menumpuk. Kerusushan dan teror bom di berbagai daerah terus bergolak seakan tidak mengindahkan tatanan kehidupan berbangsa dan bernegara. Pengadilan oleh massa kepada salah seorang yang dianggap berbuat salah sudah sedemikian kerasnya dan membudaya. Tak heran jika kemudian seorang yang dituduh pencopet dan dukun santet harus mengalami kematian yang tragis, dianiaya dan dibakar ramairamai tanpa beban dan rasa kemanusiaan.

Ulul Albab, Vol. 4 No. 1, 2003 
Lantas apa yang harus kita lakukan sebagai bangsa yang berbudaya dan beragama? Bagaimana peran pendidikan agama kita? Bagaimanakah seharusnya arah dasar Pendidikan agama Islam di sekolah, utamanya pada tingkat dasar dan menengah (MI-MA)? Apakah pendidikan agama hanya sekadar membawa peserta didik menjadi beragama (to be religion) bukan to have a religion?

\section{Reorientasi Makna}

Dalam perspektif Islam, pendidikan dikenal dengan beberapa istilah, yaitu: tarbiyah, ta'lim, ta'dib, tadrib, dan irsyad. Abdurrahman al-Nahlawy (1979) mengatakan bahwa tarbiyah adalah istilah yang paling tepat untuk menyebut pendidikan Islam. Berbeda dengan Jalal, istilah ta'lim menurutnya lebih memiliki pesan yang luas dan umum jika dibandingkan dengan istilah tarbiyah (lihat Abdul Fatah Jalal,1977). Sementara itu Naquib al-Atas (1980) beranggapan, bahwa $t a ' d i b$ adalah term yang lebih tepat untuk mewakili sebutan pendidikan Islam. Meskipun term-term di atas masih diinterpretasikan berbeda oleh sejumlah pakar, namun yang jelas konsep pendidikan dalam perspektif Islam seharusnya mengandung pesan yang lebih universal.

Terkait dengan peranan pendidikan agama yang dikembangkan di madrasah, sudah efektifkah pendidikan agama yang selama ini diberikan kepada anak didik kita? Bagaimana dengan muatan-muatan materi pendidikan agama yang tertuang dalam buku ajar?

Jika pendidikan agama bukanlah sekadar memberikan pelajaran agama secara teratur oleh guru di sekolah, melainkan penanaman jiwa agama yang dimulai dari pendidikan keluarga sejak kecil, dengan jalan membiasakan anak untuk berbuat baik, maka seperti apakah pemaknaan pendidikan agama dalam sekolah itu?

Menurut Dimyati (2002) pendidikan agama memiliki cakupan yang sangat luas, kompleks dan multidimensional. Dalam pandangannya, pendidikan agama adalah pendidikan yang bertugas 1). menggarap bakat non rasional, yaitu pada aspek rasa dan keimanan, 2). melakukan universalisme manusia secara utuh, eksistensial emansipatoris, 3). menggarap dimensi individual, sosial, moral dan kepribadian, mengingat budaya agama yang imperatif, 4). menggarap individu yang terkait dengan tradisi di mana ia melangsungkan hidupnya, 5). kegiatan yang bersifat 
universal yang berangkat secara individual dan menimbulkan seseorang yang unik, 6). membangkitkan seseorang yang beriman dan bertaqwa, beramal saleh dan mengagamakan pribadi secara lintas sosial, budaya, agama dan lintas psikologi universal.

Dari pandangan tersebut, pesan-pesan materi pendidikan agama setidaknya harus mencerminkan sifat toleran, inklusif, humanis, egaliter, pluralis dan tidak normatif-doktriner, intoleran, eksklusif, lebih-lebih absolut. Ditegaskan bahwa pendidikan agama utamanya Islam, adalah usaha sadar untuk menyiapkan siswa dalam meyakini, memahami, menghayati dan mengamalkan agamanya melalui kegiatan bimbingan, pengajaran dan atau latihan dengan memperhatikan tuntutan untuk menghormati agama lain dalam hubungan kerukunan antar umat beragama dalam masyarakat.

Berangkat dari pengertian yang sama, Bafadal (2002) membagi dua visi dan misi pendidikan agama. Pertama, pendidikan agama yang diarahkan pada peningkatan keimanan, pemahaman, penghayatan dan pengamalan siswa terhadap agama tersebut. Kedua, Pendidikan agama diarahkan pada upaya pembentukan kesadaran siswa untuk menjadi seorang muslim yang mampu menghormati agama lain dalam hubungan kerukunan antar umat beragama dalam masyarakat. Masih menurutnya orientasi pendidikan agama tidak cukup hanya menyangkut hal-hal luar, sebagaimana yang telah diungkap di atas, yaitu seperti upacara, peraturan, ritus, hukum, lambang-lambang dan sederet kesalehan ritual formalistik lainnya. Pendidikan agama tidak bisa disamakan dengan segi-segi formal itu. Meski iajuga merupakan bagian penting dalam agama.

Perbincangan soal upaya perbaikan kualitas pendidikan, khususnya pada pendidikan agama terasa sangat dilematis. Di satu sisi guru masih dilihat sebagai satu-satunya elemen terpenting, sehingga kualitas pendidikan apapun harus dimulai dari guru (Kompas,28/03/2002). Sementara itu Gorton (dalam Bafadal, 2002) telah menempatkan muatan buku ajar sebagai elemen yang secara bersamaan juga harus diperhatikan. Padahal selama ini perhatian serius di seputar materi buku ajar yang ada di MI-MA - sebagai mana yang diteorikan Gorton — belum banyak dilakukan.

Ada kesan bahwa materi yang tertuang dalam buku ajar selama ini baru menyentuh pada aspek formal dan parsial, misalnya upacara, ritus, hukum dan lambang-lambang, -meski hal tersebut harus diakui sebagai bagian yang tak terpisahkan dari nilai universal agama. Sementara spirit atau ruh dari hukum tersebut,

Ulul Albab, Vol. 4 No. 1, 2003 
yaitu iman, harapan, kasih sayang belum banyak disentuh. Dengan kata lain, pendidikan agama selama ini terjebak pada upaya membuat orang sekadar beragama, dan tidak mendorong untuk beriman. Padahal religiusitas adalah sikap dasar yang membuat orang beramal baik, bersikap penuh belas kasih, merasa rindu dan ingin dekat dengan Tuhan, penuh cinta dan sayang, lembut hati dan mudah memaafkan sekaligus memiliki solidaritas kemanuisaan universal. Inilah persoalan yang sangat inti dalam beragama yang seharusnya menjadi potret pendidikan agama di sekolah/madrasah.

Pendidikan agama sekarang ini terkesan membuat orang menjadi suci, taat pada peraturan agama dengan sedetail-datailnya, tetapi kurang menyentuh pada masalah-masalah sosial. Pendidikan semacam ini akan membentuk anak menjadi saleh tetapi picik, arogan dan ingin menang sendiri (Beny Susetyo, 2002).

Hasil observasi yang diadakan oleh PPIM (Pusat Penelitian Islam dan Masyarakat) IAIN Syarif Hidayatullah Jakarta telah mengungkap hal yang sama. Bahwa perilaku keberagamaan dari sejumlah kota-kota besar yang ada di Indonesia mayoritas masih menekankan pada dimensi kesalehan individual. Bersamaan dengan itu pula, fenomena $\mathrm{KKN}$, intoleran, miskin solidaritas, kerusuhan, kekerasan, eksploitasi, hegemoni juga marak di mana-mana. Padahal fenomena secam ini akan mudah dilerai melalui pendekatan pendidikan agama yang perhatian pada wawasan individul dan sosial secara bersamaan.

Dengan demikian konsep tentang pentingnya pendidikan bagi terciptanya kerukunan adalah sangat urgen. Dari kajian ini pula, sepintas kita telah memahami dimana letak kelebihan dan kekurangan model pendidikan agama yang diberlakukan oleh Departemen Agama. Di sinilah perlu ada penelitian lanjut terhadap pesanpesan materi yang tertuang dalam buku ajar yang merumuskan persoalan tersebut. Persoalan ini mesti segera dicarikan jalan keluamya, sehingga doktrin-doktrin agama menjadi semakin bermakna bagi terciptanya kehidupan yang harmonis antarumat beragama dalam kehidupan berbangsa dan bernegara dimaksud.

Samuel P. Huntington dalam bukunya The Clash of Civilization and the Remarking of Word Order (1996) mengatakan, bahwa benturan yang terjadi antar peradaban sangatlah besar pengaruhnya terhadap perdamaian dunia. Dalam konteks dunia internasional peradaban merupakan pengaman terpenting dalam mencegah terjadinya perang dunia. Padahal yang disebut sejarah peradaban ialah sejarah manusia itu sendiri. Sementara agama adalah karakteristik utama yang mencirikan

Ulul Albab, Vol. 4 No. 1, 2003 
sebuah peradaban. Lebih dari itu Christopler Dowson mengatakan bahwa agamaagama besar adalah bangunan dasar bagi peradaban-peradaban besar.

Tidaklah salah jika dikatakan bahwa sejarah peradaban adalah sejarah manusia, karena pada realitanya manusiaadalah makhluk yang berbudaya, beretika. Oleh karenanya ia membutuhkan pendidikan dan pengajaran untuk mendewasakan dan memajukan dirinya. Sementara dalam upaya memajukan dirinya harus melalui pendidikan agama (al-tarbiyah al-diniyah) (lihat, Bratayana, 2002).

Dengan kata lain agama yang dipentingkan bukan huruf-huruf yang tersusun menjadi hukum, namun yang lebih penting dari itu semua adalah roh/semangat dari agama itu sendiri, yaitu iman dan kasih sayang. Karena dengan pendidikan model terakhir ini, diharapkan anak didik akan menjadi manusia yang memiliki kepribadian ideal, jiwa solidaritas yang tinggi, jujur, adil, damai, rukun dan jauh dari perpecahan, kekerasan, konflik dan ketegangan antarumat beragama. Orientasi pendidikan semacamnya juga akan terlihat secara jelas ketika diletakkan pada kompleksitas dan pluralitas agama.

Di sini pluralisme agama setidaknya harus menjadi kekuatan konstruktiftransformatif, bukan sebaliknya menjadi kekuatan destruktif. Potensi pertama, yaitu kekuatan konstruktif-transformatif akan berkembang jika masing-masing komunitas agama memahami dan menjunjung tinggi nilai toleransi dan kerukunan. Sebaliknya potensidestruktif akan dominan jika masing-masing komunitas agama tidak memiliki sikap toleran, bahkan memandang inferior agama lain (Alwi Shihab, 1998: 45).

Sudah saatnya umat beragama mengkaji ajaran agamanya secara benar dan kritis, tidak terjebak pada persoalan-persoalan yang formalistik dan bersifat simbol belaka dan memulai mengorientasikan pendidikan pada substansi ajarannya yang penuh perhatian terhadap persoalan kemanusiaan dan akhlaq-karimah seperti: keadilan, kejujuran dan kedermawanan terabaikan.

Oleh sebab itu salah satu hal yang perlu diperhatikan dalam menciptakan kerukunan antarumat beragama di Indonesia adalah: pertama, pendidikan agama harus mampu membentuk watak siswa, bahwa agama merupakan kebutuhan ruhani bagi penciptaan kerukunan dan kedamaian, pemupuk persaudaraan dan ketentraman sesuai dengan misinya. Atau dengan kata lain, perlu ada reorientasi pendidikan agama yang berwawasan pada kerukunan umat dan keramahan (rahmatan lil alamain). Kedua, upaya peningkatan kualitas pendidikan pada masing-masing 
umat. Pendidikan dimaksud adalah pendidikan yang melahirkan akhlak karimah dengan indikator: adanya sikap jujur, tenggang rasa, dan cinta-kasih antar sesamanya. Bukan pendidikan yanghanya sekadar mengedepankan intelek, tetapi kemudian melahirkan manusia-manusia korup. Reorientasi pendidikan agama di atas sudah saatnya dimulai dari TK hingga perguruan tinggi dengan merubah kurikulum kita selama ini.[]

\section{DAFTAR PUSTAKA}

Abdu al-Fatah al-Jalal, Min al-Ushul al-Tarbiyah Fi al-Islam, Mesir, Daru alKutub, 1977

Abdurrahman al-Nahlawy, Ushulu al-Tarbiyah al-Islamiyah Wa Asalibuha $f i$ al-bait wa al-Madrasah wa al-Mujtama, Damsyik, Daru al-Fkri, 1979.

Alwi Shihab, Islam Inklusif, Mizan, Bandung, 1998

Bratayana, Jurnal Toleransi, Dialog Lintas Agama, Vol. 2 No. 3, 2002

Ibrahim Bafadal, Telaah Kurikulum Bidang Studi Pendidikan Agama Islam, Jurnal Toleransi, Dialog Lintas Agama, Vol. 2 No. 3, 2002.

Kompas, Kamis/28/ Maret 2002.

Moh. Dimyati, Reorientasi dan Opersionalisasi Penjabaran Kurikulum Bidang Studi Pendidikan Agama pada Sekolah Lanjutan Atas, Jurnal Toleransi, Dialog Lintas Agama, Vol. 2 No. 3, 2002.

Samuel P. Huntington, the Clash of Civilization and the Remarking Word Order, 1996.

Syed Muhammad al-Naquib al-Atas, The Concept of Education in Islam: $A$ framework for an Islamic Philosophy of Education, Kuala Lumpur Muslim Yauth Movement of Malaysia, 1980. 